FIGURES. (Plate XIX, this volume).

Turbinella pyrum Lam.

1. Rhachidian and one lateral tooth.

2. End of siphonal fold, the right mantle edge cut away to show the internal fold.

3. Extremity of proboscis from above.

4. Extremity of left tentacle, with eye.

5. General outline of radula.

6. Turbinella pyrum Lamarck, crawling.

\title{
A REVIEW OF THE AMERICAN "GOLDEN WARBLERS."
}

HY IO ERTT RIDGWAY.

In a short paper* published in the Proceedings of the Biological Society of Washington, vol. iii, pp. 1-4, I briefly characterized a new form of this group from the island of Cozumel, Yucatan, under the name of Dendroica petechia rufivertex. The birds of this group being much confused, it was found necessary, before the status of the Cozumel bird could be determined, to carefully examine all the material available (embracing considerably more than one hundred specimens from tropical America, besides a very extensive series of $D$. cestiva from North America); and as the results of this examination may be of interest, a brief synopsis is herewith presented, together with a fuller diagnosis of the Cozumel form, and also another new one from Lower California and western Mexico:

\section{+ Dendroica petechia Rufivertex.}

Dendroica petechia rufivertex, RIDGw. Proc. Biol. Soc. Washington, vol. iii, Feb. 26, 1885 , p. 1.

Subsp. Char.-Similar to D. petechia ruficapilla (Gmel.), of St. Thomas and other Lesser Antilles, but with shorter wings and tail, and rather more intense coloration.

Adult ô (type No. 102508, U. S. Nat. Mus., Cozumel I., Yucatan, January 28, 1855 ; J. E. Benedict and T. Lee): Whole crown orangerufous, the feathers rich gamboge-yellow basally. Nape, back, scapulars, and rump bright yellowish olive green; upper tail-coverts similar, but edged with yellow. Wings blackish dusky, the feathers broadly margined with olive-yellow (almost pure yellow on the coverts and tertials). Outer webs of rectrices dusky, edged with olive-green; inner webs chiefly bright primrose-yeliow. Lower parts, including whole side of head, very rich fine gamboge-yellow, the jugulum, breast, sides, and flanks broadly streaked with rich chestnut-rufous; throat with much smaller and indistinct streaks. Wing, 2.40 ; tail, 2.05 ; culmen, .55; bill from nostril, . 30 ; tarsus, .80 ; middle toe, .45.

* "Descriptions of some new species of birds from Cozumel Island, Yucatan." 
Seven adult males agree closely in the characters given above. There is some variation, however, which it may be well to note. Two specimens have the whole throat distinctly streaked, while two have scarcely a trace of these streaks, the others being intermediate. All have the whole crown bright orange-rufous, except one, in which only the anterior part of the crown is of this color. The color of the crownpatch is not so dark as in 1). rufo-pileata from Old Providence (see these "Proceedings," vol. vii, p. 173), neither is it abruptly outlined as in that species and $D$. capitalis Lawr., from Barbadoes. The relationships of this form are decidely with $D$. petechia ruficapilla and $D$. petechia melanoptera, of the Lesser Antilles, difference of proportion being the chief distinction, the former being larger, the latter smaller, than the Cozumel race.

It is with much reluctance that $I$ here present an additional race of this perplexing group; and it is only after the most careful consideration of the subject that I have concluded to do so. Anomalies in the distribution of the several local forms indicate the importance of distinguishing them by name, in order that the subject may be more conveniently handled.

The group is a most interesting and at the same time very perplexing one. In most forms the characters are easily recognizable, the differentiation having reached a point which may'be regarded as specific. In other cases the differentiation, while equally constant, is comparatively slight, and perhaps best considered as of subspecific value only. Proceeding on this basis, the group of "Golden Warblers," as at present known, may be arranged as follows, the arrangement here presented being based on more than one hundred adult males:

A. Tarsus usually less, and never more, than .75 of an inch; head of adult male yellow, the crown more olivaceous, and never with a distinct suffusion or patch of rufous.

1. D. æstiva (GM.).-Hab. Continental; whole of North America, south in winter through Central America, to Colombia, Venezuela, Guiana, Trinidad, and Tobago.

B. Tarsus usually more, and never less, than .75 of an inch.

a. Head of adult male yellow, the crown with a distinct suffusion of orangerufous.

\section{D. petechia.}

$+\alpha$. petechia (Linn.).-Hab. Jamaica; Hayti?

Motacilla petechia, Lins.-Dendroica petechia Scl.

Dendroeca petechia, (e) jamaicensis Sund.

+ B. gundlachi BaIRD.-Hab. Cuba; Bahamas.

Dendroica gundlachi BAIRD.-D. petechia, var. gundlachi B. B. \& R.

Dendroeca petechia $(d)$ cubana SUND.

+ $\gamma$. ruficapilla (FM.).-Hab. Porto Rico; St. Thomas; St. Croix; St. Bartholomew; St. Kitts; St. Eustatius ; Antigua ; Martinique? ?

Motacilla ruficapilla GMEL.-Dendroica ruficapilla BAIRD, Review.Dendroica petechia, var. ruficapilla B. B. \& R.

Dendroeoa petechia (a) bartholemica Sund.

Dendroeca petechia (b) cruciana SUND. 
$+\delta$. melanoptera, LAwr.-Hab. Guadeloupe; Dominica.

Dendroica petechia, var. melanoptera LAwR.

$+\varepsilon$. rufivertex RIDGW.-Hab. Cozumel I.. Yucatan.

+ $\xi$. aureola (GoULD).-Hab. Galapagos Islands.

Sylvicola aureola, GouLD.-Dendroica aureola BAIRD.

Dendroeca petechia (f) gallapagensis Sund.

$b$. Head of adult male yellow, the crown with a sharply defined patch of rufous or chestnut.

+3. D. capitalis LAwR.-Hab. Barbadoes.

Dendroica capitalis LAWR.; BAIRD; B. B. \& R.

Dendroeca petechia (c) barbadensis Sund.

+ 4. D. rufo-pileata Ridgw.--Hab. Island of Old Providence, Càribbean Sea.

c. Head of adult male entirely rufous or chestnut.

+5 . D. rufigula BAIRD. - Hab. Martinique.

6. D. vieilloti CAss.

Dendroica rufigula BAIRD.

+ a. vieilloti CASS. - Hab. Northern Colombia (Cartagena).

+ . panamensis Sund.-Hab. Panama; Costa Rica (Nicoya).

Dendroeca petechia (i) panamensis Sund.

Dendroica rieilloti Cass. (part; specs. ex Panama).

7. D. bryanti RIDGW.

Dendroica vieilloti, var. rufigula B. B. \& R. (nec D. rufigula BAIRD).

$+c$. bryanti RIDGw.-Hab. Atlantic coast, Belize to Northern Yucatan (Merida). Dendroica vieilloti, var. bryanti, RIDGw.; B. B.\& R.

$\beta$. castaneiceps RIDGw.*-Hab. Western Mexico (Mazatlan); Cape St. Lucas.

SUBSP. CHAR.-Differing from true D. bryanti in having the head rich chestnut instead of rufous. Adult ơ (type, No. 89940, U. S. Nat. Mus., La Paz, Lower California, Dec. 16, 1882 ; L. Belding): Head rich chestnut, lighter or more rufous on the throat. Upper parts olive-green, the wings dusky, with broad greenish yellow edgings; outer webs of rectrices dusky, edged with yellowish olive-green, the inner webs chiefly prinrose-yellow. Lower parts bright gamboge-yellow, the jugulum and breast with a few very indistinct and mostly concealed streaks of chestnut-rufous. Bill dusky. Feet, dark born-color. Wing, 2.70; tail, 2.20 ; culmen, .58; bill from nostril, . 35 ; tarsus, .80 ; middle toe, .49 .

Adult 우 (No. 89942, U. S. Nat. Mus., La Paz, Lower California, December 29, 1882): Above grayish olive-green; wings grayish dusky, the feathers edged with olive-grayish; rectrices dusky, outer webs edged with olive-green, the inner with primrosesellow. Lower parts dull pale olive-yellowish. Wing, 2.50 ; tail, 2.10 ; culmen, .55; bill from nostril, . 30 ; tarsus, .80 ; middle toe, .45 .

Hab.-Western Mexico (vicinity of Mazatlan) and vicinity of La Paz, Lower California.

The male selected as the type is the one having the head lightest in color of the three Lower Californian examples before me. The other two differ as follows:

No. 86260, U. S. Nat. Mus., La Paz, January 6, 1882 ; L. Belding: Head slightly darker chestnut, especially the pileum; breast with the streaks rather more distinct (but still very faint), and sides similarly streaked. Wing, 2.60 ; taii, 2.25.

No. 89938, La Paz, December 19,1 1^82; L. Belding: Head still darker chestnut than in No. 86260. Streaks on lower parts about the same. Wing, 2.60 ; tail, 2.10.

Young males, obtained in December, are similar to the female, as described, but brighter in color and with the head more or less touched or mixed with chestnut.

Two adult males from Mazatlan are essentially identical with the La Paz specimens. They measure as follows:

No. 58252, Mazatlan; Col. A. J. Grayson: Wing, 2.50; tail, 2.10.

No. 35017, Mazatlan, August; Col. A. J. Grayson: Wing (molting); tail (molting). "Bill black above, margined with paler; under mandible lead-color." 


\section{$2 \mathrm{BHL}$ Biodiversity Heritage Library}

Ridgway, Robert. 1885. "A review of the American "golden warblers"." Proceedings of the United States National Museum 8, 348-350.

View This Item Online: https://www.biodiversitylibrary.org/item/52770

Permalink: https://www.biodiversitylibrary.org/partpdf/50998

\section{Holding Institution}

Smithsonian Libraries

\section{Sponsored by}

Smithsonian

\section{Copyright \& Reuse}

Copyright Status: Public domain. The BHL considers that this work is no longer under copyright protection.

This document was created from content at the Biodiversity Heritage Library, the world's largest open access digital library for biodiversity literature and archives. Visit BHL at https://www.biodiversitylibrary.org. 